\title{
Bacteria or melanosomes? A geochemical analysis of micro-bodies on a tadpole from the Oligocene Enspel Formation of Germany
}

\author{
Holly E. Barden • Uwe Bergmann • Nicholas P. Edwards • \\ Victoria M. Egerton • Phillip L. Manning • Sarah Perry • \\ Arjen van Veelen $•$ Roy A. Wogelius • Bart E. van Dongen
}

Received: 30 May 2014 / Revised: 9 October 2014 / Accepted: 9 October 2014 /Published online: 19 November 2014

(C) The Author(s) 2014. This article is published with open access at Springerlink.com

\begin{abstract}
Many exceptionally preserved fossils have long been thought the product of preservation by bacterial autolithification, based largely upon the presence of, micronsized, spherical or elongate bodies on their surface. This has recently been challenged by studies of similar fossils which cite morphological and geochemical evidence that these structures could be fossilized melanosomes, melanin-containing organelles. We geochemically analysed a tadpole from the Oligocene Enspel Formation, Germany, which displays such spherical bodies on its surface. Pyrolysis gas chromatography mass spectroscopy (Py-GCMS) and Fourier transform infrared spectrometry (FTIR) indicate that the organic remains of the tadpole are original and are not the result of external contamination, shown by the different chemical compositions of the fossil and its enclosing matrix. Py-GCMS also demonstrates the presence of bacterial and plant biomarkers in the matrix but not the tadpole, suggesting that the spherical bodies are unlikely to be bacterial, and also that such fossils do not develop their dark colour from incorporating plant material, as has been suggested. X-ray absorption spectroscopy (XAS)
\end{abstract}

This article is a contribution to the special issue "The Fossil-Lagerstätte Enspel - reconstructing the palaeoenvironment with new data on fossils and geology".

Electronic supplementary material The online version of this article (doi:10.1007/s12549-014-0177-5) contains supplementary material, which is available to authorized users.

H. E. Barden $(\varangle) \cdot$ N. P. Edwards • V. M. Egerton • P. L. Manning • S. Perry · A. van Veelen $\cdot$ R. A. Wogelius $\cdot$ B. E. van Dongen

School of Earth, Atmospheric, and Environmental Sciences, Williamson Research Centre for Molecular Environmental Science, University of Manchester, Oxford Rd, Manchester M13 9PL, UK

e-mail: holly.barden@manchester.ac.uk

U. Bergmann

SLAC National Accelerator Laboratory, Stanford Synchrotron

Radiation Lightsource, Menlo Park, CA 94025, USA shows high levels of organically bound $\mathrm{Zn}$ (II) in the fossilized soft tissue, a metal known to chelate both eu- and pheomelanin. The zinc in the tadpole shows greater similarity to that bound in pheomelanized extant samples than to that in eumelanized ones. Though further geochemical analysis of both pure pheomelanin and bacterial samples is required to completely exclude a bacterial origin, these results are in line with a pheomelanic origin for the spherical bodies on the tadpole.

Keywords Enspel · Bacterial autolithification - Amphibian · Melanin $\cdot$ Melanosomes $\cdot$ Geochemistry

\section{Introduction}

Bacterial autolithification has been a widely accepted taphonomic model for the exceptional preservation of fossil organisms that has been studied across various taxonomic groups and geological formations (Wuttke 1992; Wilby et al. 1996; Briggs et al. 1997, 2005; Gehling 1999). The process is particularly a characteristic of the Oligocene Enspel Formation of Germany and was first described by Wuttke (Wuttke 1983; Cristol et al. 2005) after the observation of coccoid or bacillus cell-like structures within fossilized soft tissues. The phenomenon involves the mineralization of the cells in a bacterial mat that has covered a carcass (Briggs et al. 2005), caused by the precipitation of either siderite, utilising iron from the surrounding sediments (Franzen 1985; Wuttke 1992), or apatite, where the phosphorus from the decaying organism has become trapped by the mat (Briggs and Wilby 1996; Briggs et al. 1997). The typically black colour of the preserved soft tissues is thought to be derived from the subsequent incorporation of organic matter from plants to form a carbonized film (Franzen 1985).

In recent years however, the structures thought to be fossil bacterial cells have in many cases been reclassified as fossilized melanosomes, the membrane-bound organelles in which 
the chemical pigment melanin is synthesized. This reinterpretation is based on a growing number of studies citing both morphological (Vinther et al. 2008; Clarke et al. 2010; Zhang et al. 2010; Li et al. 2010, 2012; Carney et al. 2012) and geochemical evidence (Barden et al. 2011; Wogelius et al. 2011; Glass et al. 2012; Lindgren et al. 2012, 2014), though the debate is by no means settled (Moyer et al. 2014). Extant melanosomes are known to exist in both spherical and elongate forms depending on the type of melanin they contain (Liu et al. 2005), though this is not always the case (Liu et al. 2005). Thus far, such a combination of geochemical techniques has not been applied to the study of fossilized amphibians, though some fossil tadpoles from the Enspel Formation are known to have dense layers of sub-micrometre-sized spherical bodies within their soft tissues (Toporski et al. 2002). In this study, we performed detailed geochemical analysis of a fossil tadpole from the Enspel Formation to look for biomarkers indicative of the preservation of melanin or bacteria. Such analyses will not only give great insight into the taphonomy of the organism (Gupta et al. 2007a, b) but can also help to improve our understanding of its original biochemistry.

\section{Materials and methods}

\section{Samples and handling}

The fossil tadpole is composed of both part (FS003a) and counterpart (FS003b; Fig. 1a, b). The samples were collected in the summer of 2011 from the black shale layers, section S12 of the Enspel Formation, and were wrapped in aluminium foil to reduce contamination. Sampling and identification were carried out by Dr M. Wuttke (personal communication). The material is housed at the University of Manchester.

The tadpole appears to be broken in half with the end of the tail curling round to meet the head (Fig. 1a, b). Preservation is too poor to allow species identification with any confidence and also makes assignment of growth stage difficult. In addition, though no legs are apparent, the tadpole lays on the edge of the block leaving the possibility that either it became disassociated from the main organism or was separated from the main body during collection. As measured from the part (FS003a), the tadpole is $67 \mathrm{~mm}$ long including soft tissues. On comparison with other fossil tadpoles (Roček 2003; McNamara et al. 2010), it is likely to be between Gosner stages 36 and 37 (Gosner 1960) due to its size and apparent ossification of the skull.

Samples of redbreast feathers from an extant black-headed grosbeak (Pheucticus melanocephalus) were obtained from partially intact specimens curated at The Manchester Museum, and blonde and black human hair samples were donated by members of staff. These acted as modern pheomelanin and eumelanin standards, respectively. Zinc standards used for XAS edge calibration and for comparison to biological samples were zinc metal foil, zinc acetate $\left(\mathrm{Zn}\left(\mathrm{O}_{2} \mathrm{CCH}_{3}\right)_{2}\right)$ and zinc sulfate $\left(\mathrm{ZnSO}_{4} \cdot 7 \mathrm{H}_{2} \mathrm{O}\right)$. Zinc sulfate and acetate were purchased from Sigma-Aldrich, as was a sample of Sepia officinalis eumelanin (product number M2649). Once in the laboratory, all samples were kept in individual aluminium foil packets within sealed plastic bags. Gloves were worn at all times when handling the fossils.

Scanning electron microscopy (SEM) and energy-dispersive $\mathrm{x}$-ray spectroscopy (EDS)

Samples were analysed using both variable pressure field emission gun scanning electron microscopy (VPFEG-SEM) and conventional SEM. Extant grosbeak feathers were prepared for imaging according to Zhang et al. (2010), gold coated and mounted on an aluminium stub; fossil samples were left uncoated. All images collected were secondary electron images. A ZEISS Supra 40VP SEM was used to collect VP-SEM images of the tadpole and matrix (FS003b) at $15.0 \mathrm{keV}$ accelerating voltage and $14.5 \mathrm{~mm}$ working distance and high vacuum SEM images of the same sample at $1.0 \mathrm{keV}$ and $3.5 \mathrm{~mm}$. An FEI XL30 VP-SEM was also used to collect VP-SEM images of smaller matrix pieces (FS003b) at $15.0 \mathrm{keV}$ and $12.4 \mathrm{~mm}$ and SEM images of extant grosbeak feathers at $15.0 \mathrm{keV}$ and $12.4 \mathrm{~mm}$. Standardless EDS spectra of tadpole and matrix were taken using an EDAX energy-dispersive $\mathrm{x}$-ray spectrometer with the ZEISS Supra 40VP SEM at $15.0 \mathrm{keV}$ and $14.5 \mathrm{~mm}$ for $100 \mathrm{~s}$. Errors are estimated to be approximately $30 \%$ of the reported value. Image features were analysed using ImageJ (Schneider et al. 2012).

Pyrolysis gas chromatography mass spectrometry (Py-GCMS)

Matrix samples (FS003a) and $2.4 \mathrm{mg}$ of powdered tadpole were analysed using normal flash Py-GCMS using a Chemical Data Systems (CDS) 5200 series pyroprobe pyrolysis unit attached to an Agilent 7890A gas chromatograph fitted with an HP fused column (J\&W Scientific $5 \%$ diphenyl-dimethylpolysiloxane; $30 \mathrm{~m}, 0.32 \mathrm{~mm}$ i.d.; $0.25 \mu \mathrm{m}$ film thickness) and an Agilent 5975C MSD single quadrupole mass spectrometer operated in electron ionization (EI) mode (EI source temperature $230^{\circ} \mathrm{C}$ and MS quadrupole held at $150^{\circ} \mathrm{C}$ ) with helium as a carrier gas. Samples were pyrolysed at $600{ }^{\circ} \mathrm{C}$ for $20 \mathrm{~s}$, the pyrolysis transfer line and injected using a split ratio of $2: 1$; the injector port temperature was maintained at $350{ }^{\circ} \mathrm{C}$ and the interface at $280{ }^{\circ} \mathrm{C}$. The oven was programmed to heat from $40{ }^{\circ} \mathrm{C}$ for 3 min to $320^{\circ} \mathrm{C}$ at $4{ }^{\circ} \mathrm{C} \mathrm{min}{ }^{-1}$ held for $5 \mathrm{~min}$, and there was a solvent delay of 

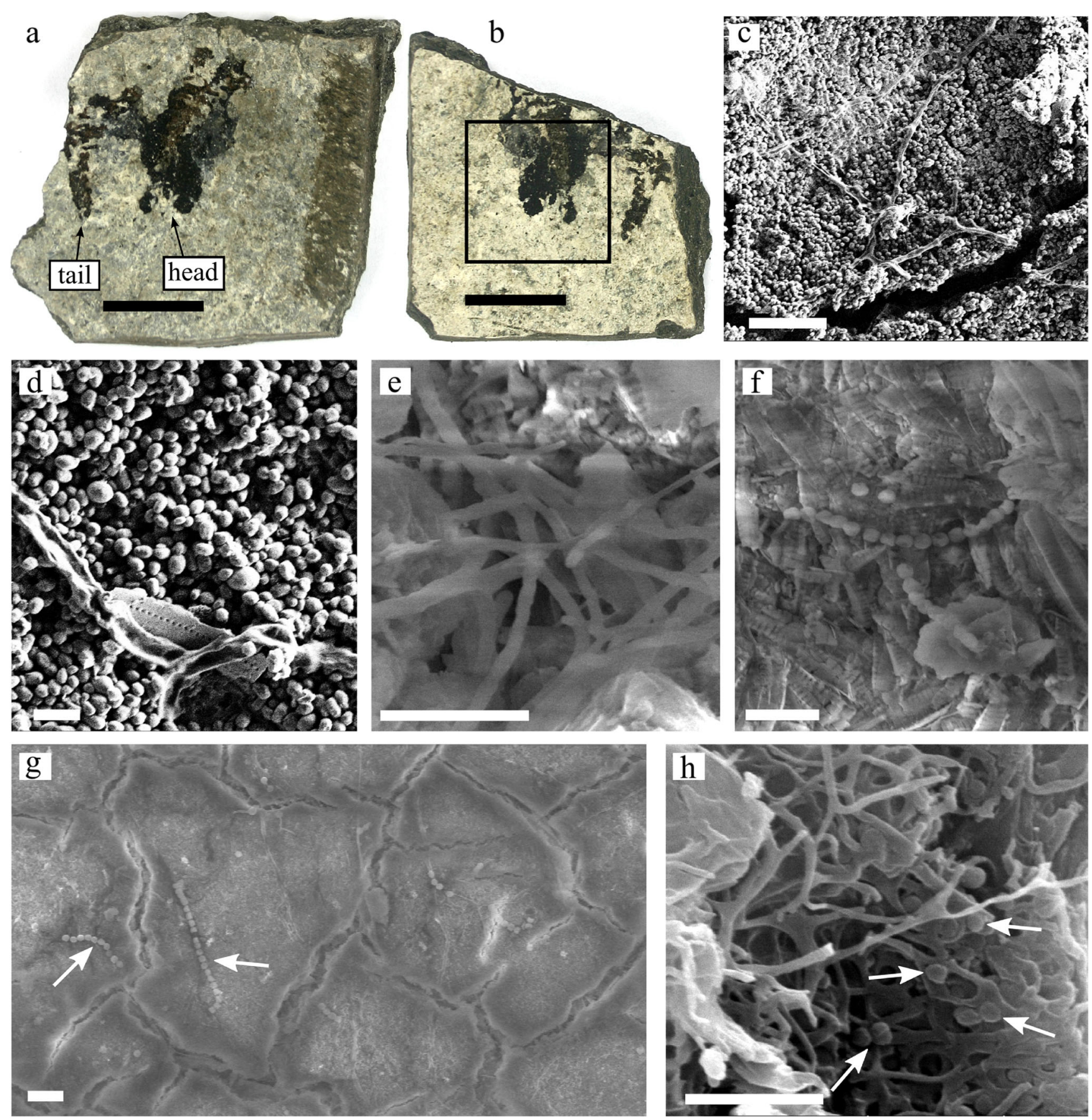

Fig. 1 Photographic images of $\mathbf{a}$ the part (FS003a) and $\mathbf{b}$ counterpart (FS003b) of the fossil tadpole from the upper Oligocene sediments of the Enspel Formation. Head and tail of the tadpole are indicated in a. The square in $\mathbf{b}$ indicates the area scanned using SRS-XRF, shown in Fig. 5. Secondary electron images show $\mathbf{c}, \mathbf{g}$ the surface of the tadpole (FS003b) as a cracked carbonized film covered in $\mathbf{c}, \mathbf{d}$ microscopic spherical bodies approximately $0.76 \mu \mathrm{m}$ in average diameter. The diatomaceous matrix
(FS003b) shows the presence of $\mathbf{e}$ organic filaments and $\mathbf{f}$ chains of spherical bodies approximately $1.6 \mu \mathrm{m}$ in average diameter; these also appear on the tadpole (white arrows in $\mathbf{g}$ ). The pheomelanosomes (white arrows) with an average diameter of $0.3 \mu \mathrm{m}$ present in the barbules of a ginger grosbeak feather are shown in $\mathbf{h}$. Scale bars represent $\mathbf{a}-\mathbf{b} 2 \mathrm{~cm}, \mathbf{c}$, e-g $10 \mu \mathrm{m}$ and $\mathbf{d}, \mathbf{h} 2 \mu \mathrm{m}$
$4 \mathrm{~min}$. Mass spectrometric detector (MSD) mass range scanned from was $\mathrm{m} / \mathrm{z} 50-650$ at one scan $\mathrm{s}^{-1}$. Thermochemolysis of samples was carried out by reaction with $10 \mu \mathrm{l}$ of tetramethylammonium hydroxide (TMAH) solution and then analysed using the same equipment with the oven programmed to heat from $40^{\circ} \mathrm{C}$ for $3 \mathrm{~min}$ to $300^{\circ} \mathrm{C}$ at $4{ }^{\circ} \mathrm{C} \mathrm{min}^{-1}$ held for $15 \mathrm{~min}$, with a solvent delay of $10 \mathrm{~min}$ and an MSD mass range of $m / z 60-700$ at one scan $\mathrm{s}^{-1}$. 
Compounds were identified using the National Institute of Standards and Technology (NIST) database and by comparison with spectra from the literature.

\section{Fourier transform infrared spectroscopy (FTIR)}

Spectra of the tadpole and matrix (FS003b) and a eumelanin standard were taken in Attenuated Total Reflectance (ATR) mode with a germanium crystal using a Spotlight 400 PerkinElmer FTIR imaging system (wave number range $4000-650 \mathrm{~cm}^{-1}$ ). Scans were taken with an aperture of $20 \mu \mathrm{m}^{2}$ and a $4 \mathrm{~cm}^{-1}$ resolution; each spectrum is an average of ten scans and is background subtracted. The ATR crystal was cleaned using isopropanol after each scan to avoid cross contamination. Peaks were identified using the Bio-Rad KnowItAll Informatics System 8.2 Multi-Technique database. Inorganic bands were identified by comparison with spectra from the RRUFF mineral database (Downs 2006).

\section{Synchrotron rapid scanning x-ray fluorescence (SRS-XRF)}

SRS-XRF analysis of tadpole and matrix (FS003b) was carried out at wiggler beamline 6-2 of the Stanford Synchrotron Radiation Lightsource (SSRL). Scans were undertaken in ambient conditions with a beam energy of $13.5 \mathrm{keV}$ and a flux of $1.5 \times 10^{11}$ photons $\mathrm{s}^{-1}$. A pinhole aperture was used to generate a beam spot size of $50 \mu \mathrm{m}$, and samples were mounted on an X$\mathrm{Y}$ motorized stage at a fixed $45^{\circ}$ incident angle to the beam. Fluoresced x-rays were detected using a single element drifted (Vortex) detector fixed at a $90^{\circ}$ scattering angle to the beam and $70 \mathrm{~mm}$ from the sample. Zinc, copper and calcium were mapped with energy windows $350 \mathrm{eV}$ wide to capture their respective characteristic x-ray emission line intensities. Point analyses were taken by locating and driving the mounted sample to a point of interest and collecting a full energydispersive spectrum for $100 \mathrm{~s}$. Spectra were calibrated by comparison with a point analysis from a Durango apatite standard of known elemental composition. Errors are conservatively estimated to be approximately $\pm 40 \%$. Spectra were fit using PyMCA software from fundamental parameters (Solé et al. 2007). Further details of methods are published in Bergmann et al. (2012), Anné et al. (2014) and Edwards et al. (2014).

\section{X-ray absorbance spectroscopy (XANES and EXAFS)}

X-ray absorbance near-edge structure spectroscopy (XANES) and extended $\mathrm{x}$-ray absorbance fine structure (EXAFS) spectra were collected for FS003b at the microfocus beamline I18 of the Diamond Light Source synchrotron. The fossil material and extant human hair were analysed under fluorescence mode, the zinc standards in transmission mode. The emitted intensity of the zinc $\mathrm{K} \alpha$ line was recorded as a function of incident beam energy. A linear combination analysis was carried out in Athena version 071 (Ravel and Newville 2005).

Zinc K edge EXAFS were obtained using Kirkpatrick-Baez mirrors to produce a spot size of approximately $5 \mu \mathrm{m}$, a double crystal Si (111) monochromator to scan incident beam energy, and a 4-element Vortex silicon drift detector. Flux was estimated to be between $10^{11}$ and $10^{12}$ photons $\mathrm{s}^{-1}$. A zinc metal foil was used to calibrate edge energy. Data were analysed with SIXpack (Webb 2005) fit with FEFF6 using reference scattering paths.

Number of atoms $(n \pm 1)$, radial distance $(R \pm 0.01 \AA)$ and the Debye-Waller factor $\left(\sigma^{2}\right)$ are all best fits for all shells at the optimized local coordination geometry: i.e. the geometry corresponding to the minimum reduced $\chi^{2}$. Additional coordination shells were deemed significant if $\chi^{2}$ decreased by

$>1+2 \sqrt{\frac{2}{v}}$

(where $v$ is the degrees of freedom in the fit). All shells presented here passed this significance test.

\section{Results}

\section{SEM and EDS}

The soft tissues of the tadpole are composed of a thin film which has become cracked into a number of interconnected polygonal shapes (Fig. 1g). The surface of the film is covered in a dense layer of spherical bodies (Fig. 1c, d) $0.76 \mu \mathrm{m}$ in diameter $\pm 18 \mathrm{~nm}$ (average of ten measurements), as well as amorphous filamentous material occasionally entangling diatom skeletons (Fig. 1d). This filamentous material also appears on the matrix (Fig. 1e), which is a diatomaceous sediment consisting of a dense mat of siliceous diatom skeletons (Fig. 1f). Also present on both tadpole (Fig. 1g) and matrix (Fig. 1f) are chains of up to 20 unidentified spherical bodies $1.6 \mu \mathrm{m}$ in diameter $\pm 18 \mathrm{~nm}$ (average of ten measurements); these could be bacterial bodies or pollen grains. Pheomelanosomes examined for comparison were found within the fractured barbules of an extant grosbeak feather (Fig. 1h). They are spherical, $0.3 \mu \mathrm{m}$ in diameter $\pm 18 \mathrm{~nm}$ (average of ten measurements), and entangled within the filamentous material within the centre of the barbules.

EDS analysis shows the matrix to be predominantly composed of silicon and oxygen whereas the tadpole is mostly carbon and oxygen with some silicon. There is also more sulfur present in the tadpole than the matrix (Table 1) as noted in previous studies (McNamara et al. 2009, 2010). Caution should be taken in interpreting absolute values due to the effects of sample topography. EDS analysis of the chained bodies and filamentous material is given in Table 1 of the electronic supplementary information. 
Table 1 Elemental composition of FS003a and FS003b, from ED and SRS-XRF analysis

\begin{tabular}{|c|c|c|c|c|c|}
\hline \multirow[b]{2}{*}{ Technique } & \multirow[b]{2}{*}{ Element } & \multicolumn{2}{|l|}{ Tadpole } & \multicolumn{2}{|l|}{ Matrix } \\
\hline & & FS003a (wt.\%) & FS003b (wt.\%) & FS003a (wt.\%) & FS003b (wt.\%) \\
\hline EDS & $\mathrm{C}$ & 43 & 47 & 8 & 6 \\
\hline EDS & $\mathrm{O}$ & 31 & 33 & 46 & 43 \\
\hline EDS & $\mathrm{Mg}$ & 1 & 1 & 0 & 0 \\
\hline EDS & $\mathrm{Al}$ & 1 & 1 & 2 & 2 \\
\hline EDS & $\mathrm{Si}$ & 13 & 8 & 40 & 46 \\
\hline \multirow[t]{2}{*}{ EDS } & $\mathrm{S}$ & 2 & 2 & 0 & 0 \\
\hline & & FS003a (ppm) & & FS003a (ppm) & \\
\hline SRS-XRF & $\mathrm{Ca}$ & 6451 & & 4182 & \\
\hline SRS-XRF & $\mathrm{Ti}$ & 3519 & & 1928 & \\
\hline SRS-XRF & $\mathrm{Fe}$ & 42,710 & & 42,440 & \\
\hline SRS-XRF & $\mathrm{Cu}$ & 254 & & 161 & \\
\hline SRS-XRF & $\mathrm{Zn}$ & 1327 & & 168 & \\
\hline
\end{tabular}

\section{Py-GCMS}

Partial $m / z 55+57$ chromatograms of both tadpole and matrix samples (FS003a) show a series of $n$-alkane/ $n$-alkene doublets, indicating the presence of an aliphatic polymer (Stankiewicz et al. 2000; Gupta et al. 2007a, b, c). The carbon chain length distribution differs between tadpole and matrix. Those in the tadpole range from $\mathrm{C}_{8}$ to $\mathrm{C}_{29}$ with maxima at $\mathrm{C}_{11}, \mathrm{C}_{17}$ and $\mathrm{C}_{21}$, whereas in the matrix, they range from $\mathrm{C}_{8}$ to $\mathrm{C}_{31}$ with maxima at $\mathrm{C}_{10}$ and $\mathrm{C}_{23}$ (Fig. 2c, d). The compounds present in both matrix and tadpole include benzene, di- and trimethyl benzene, 1, ethyl3,methyl benzene, propenyl benzene, ethyl phenol, trimethyl-diand tetrahydronaphthalene, dimethyl naphthalene and methylated alcohols. Additional compounds found only in the matrix are methyl phenol, and phytol; those only in the tadpole are methyl indene, naphthalene, methyl-dihydronaphthalene, methyl naphthalene and benzyl alcohols. Alkyl-benzenes and naphthalenes are common products in both fossil (Gupta et al. 2007b; Manning et al. 2009) and artificially matured organic material (Stankiewicz et al. 2000; Gupta et al. 2007c), most likely the products of diagenetic alteration (Gupta et al. 2007b). The partial $\mathrm{m} / \mathrm{z} 191$ chromatograms show the presence of a series of hopanes within the matrix but none in the tadpole (Fig. 2a, b, insets).

Analysis after thermochemolysis reveals a pattern of $n$ alkanoic acid methyl esters, in the partial $\mathrm{m} / \mathrm{z} 74$ chromatograms, with a distinctly different distribution pattern in matrix compared to the tadpole (Fig. 3 insets). In the matrix, the chain lengths range from $\mathrm{C}_{8}$ to $\mathrm{C}_{28}$, with maxima at $\mathrm{C}_{16}$ and $\mathrm{C}_{22}$, whereas in the tadpole, the chain lengths range from $\mathrm{C}_{14}$ to $\mathrm{C}_{18}$ with the maxima at $\mathrm{C}_{14}, \mathrm{C}_{16}$ and $\mathrm{C}_{18}$. Additional compounds present in the tadpole after such treatment are 1,3,5trimethylhexahydro-s-triazine and oleic acid. In all cases, abundances of organic moieties are higher in the matrix than in the tadpole, most likely because there are more organic sources contributing to the signal in the matrix than for that of the fossil.

\section{FTIR}

Some areas of the matrix (Fig. 4d) show a similar absorption pattern to the tadpole (Fig. 4a, b), and some show a different one (Fig. 4d). In all cases, the spectra are dominated by an inorganic silica absorption band at approximately $1100 \mathrm{~cm}^{-1}$, most likely due to the presence of diatom frustules. The slight shift in this peak potentially indicates a slight difference in mineral composition between the tadpole and matrix. The majority of absorption peaks occur between 1800 and $700 \mathrm{~cm}^{-1}$ in both tadpole and matrix, though a wide band $\mathrm{OH}$ stretch band is present at approximately $3200-3400 \mathrm{~cm}^{-1}$.

The assignment of peaks in the region 1800 and $700 \mathrm{~cm}^{-1}$ is somewhat difficult to perform with confidence due to the likely presence of inorganic mineral absorption bands, many of which occur in this area and most likely convolve with organic bands. Nevertheless, we can with reasonable confidence identify some of the major peaks as a $\mathrm{C}=\mathrm{O}$ stretch at $1750 \mathrm{~cm}^{-1}$, the amide $\mathrm{NH}$ bending group at $1550 \mathrm{~cm}^{-1}$, the $\mathrm{CN}$ amide stretch at $1410 \mathrm{~cm}^{-1}$ and the alcohol CO stretch at $1200 \mathrm{~cm}^{-1}$, all of which occur in both tadpole and matrix (Fig. 4a, b, d), though not in all of the matrix (Fig. 4c). The tadpole shows an additional alcohol $\mathrm{OH}$ deformation group at $1350 \mathrm{~cm}^{-1}$ that does not appear in the matrix and also what is most likely an alkane $\mathrm{CH}$ symmetric stretching band at 2650 $2950 \mathrm{~cm}^{-1}$, its breadth indicating the probable convolution with other unidentified peaks. There is one other prominent peak that occurs in both tadpole and matrix at $1650 \mathrm{~cm}^{-1}$ which may represent the $\mathrm{C}=\mathrm{O}$ amide I stretch. Though this is inconclusive, as an inorganic pyrite peak occurs at the same place, the presence of other amino acid groups means it is likely to be present. Spectrum b on the tadpole (Fig. 4b) shows two relatively broad peaks at approximately 1350 and $1550 \mathrm{~cm}^{-1}$ which agree well with the two major $\mathrm{C}=\mathrm{O}$ ketone and carboxylic acid peaks of the eumelanin standard (Fig. 4e). 

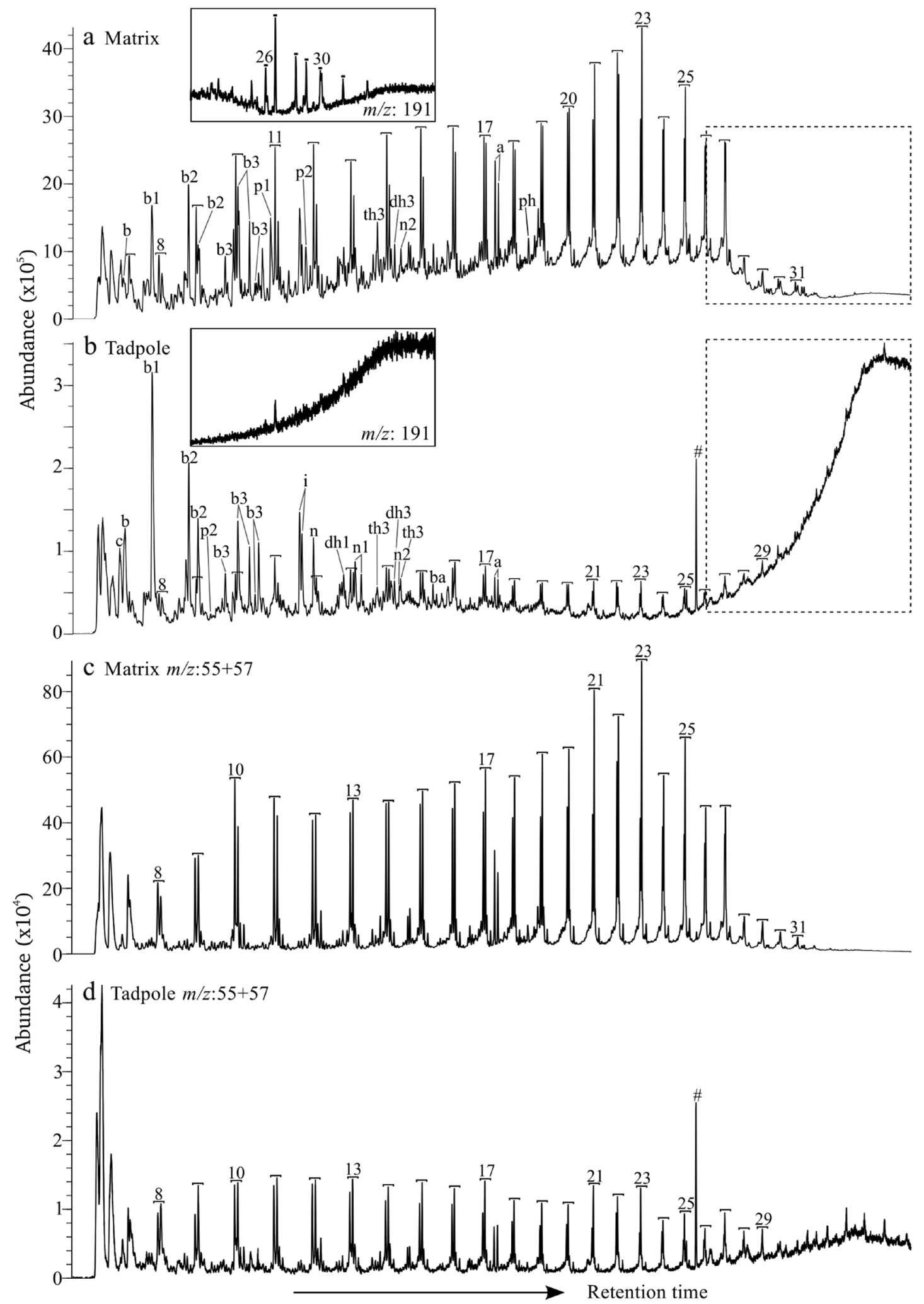

Fig. 2 Py-GCMS total ion current and $\mathbf{a}, \mathbf{b} \mathrm{m} / \mathrm{z} 55+57$ chromatograms of the c, $\mathbf{d}$ tadpole and matrix (FS003a); insets (not to scale) show the $\mathrm{m} / \mathrm{z}$ 191 mass chromatograms of the dotted areas revealing the presence and distribution of hopane groups. Brackets represent $n$-alkane/n-alkene doublets and the number sign contamination. Abundances are arbitrary. $p$ phytol, $c$ cyclohexadiene, $i$ methylindene, $b a$ benzyl alcohol, $b x$ benzene derivative, $d h x$ dihydronaphthalene derivative, thx tetrahydronaphthalene derivative, $n x$ naphthalene derivative and $p x$ phenol derivative, where $x$ represents the number of carbon atoms in the alkyl group 


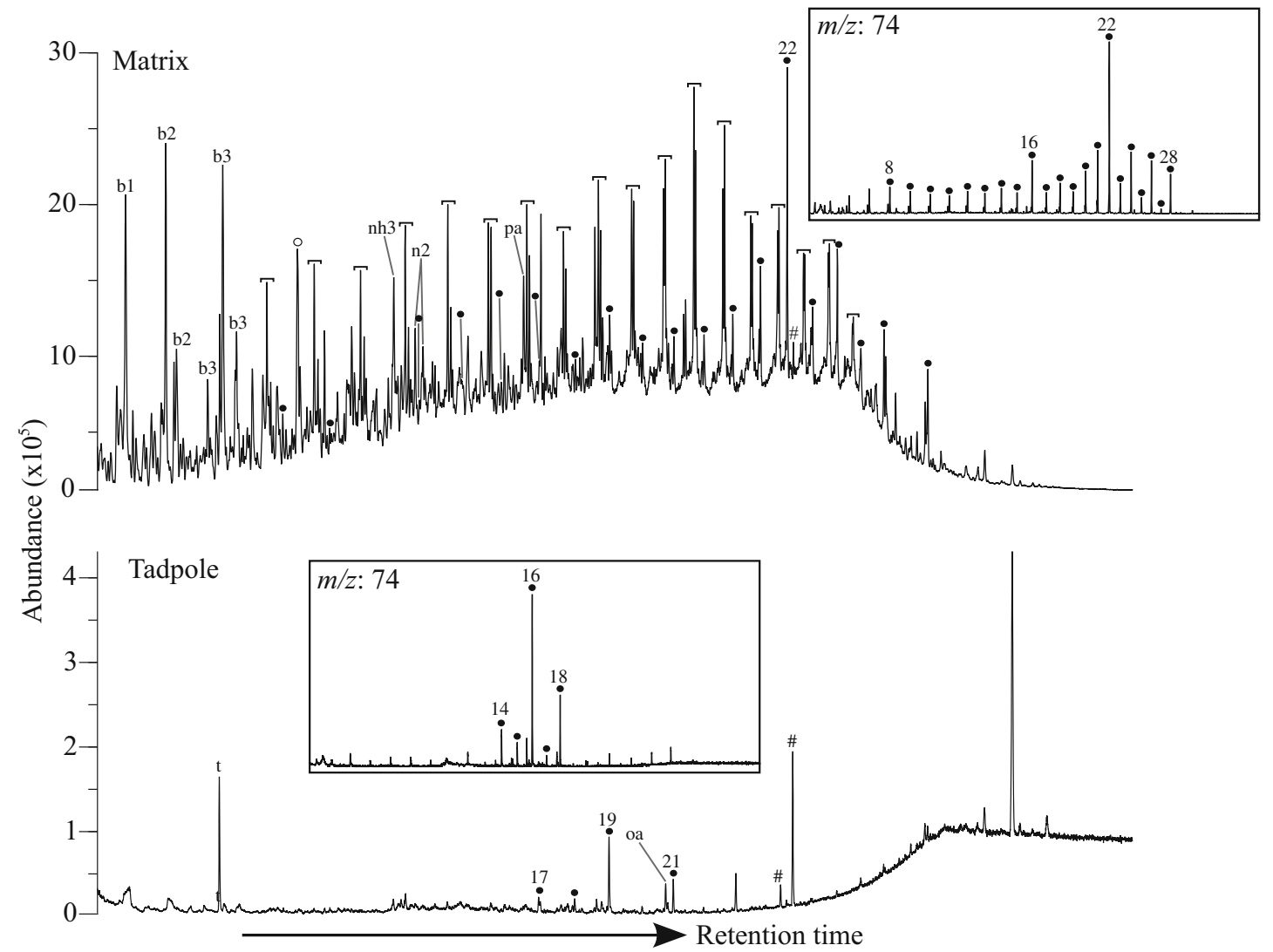

Fig. 3 Py-GCMS total ion current chromatograms of the tadpole and matrix (FS003a) after thermochemolysis. Insets (not to scale) are the $\mathrm{m} / \mathrm{z}$ 74 mass chromatograms showing the distribution of fatty acid moieties (measured as methyl esters) represented by filled circles with numbers indicating the carbon chain length. The open circle indicates unidentified compounds and the number sign contamination. Brackets represent $n$ - alkane/ $n$-alkene doublets. Abundances are arbitrary. $b x$ benzene derivative, $n h x$ tetra hydronaphthalene derivative, $n x$ naphthalene derivative (where $x$ represents the number of carbon atoms in the alkyl group), $p a$ 2-propenoic acid, 3-(4-methoxyphenyl)-,methylester, $t$ 1,3,5trimethylhexahydro-s-triazine, $o a$ oleic acid methylester
Absorption at 2364 and $2329 \mathrm{~cm}^{-1}$ is attributable to atmospheric carbon dioxide. Full peak assignments are given in Table 2 of the electronic supplementary information.

\section{SRS-XRF}

When mapped, calcium is predominantly associated with the skull area of the tadpole (Fig. 5a, b); the rest of the soft tissue is strongly associated with zinc (Fig. 5c) and anti-correlated with calcium, no other elements associate with the tadpole in such a way. Copper, which has previously been shown to be a biomarker for eumelanin (Wogelius et al. 2011), shows no correlation with the soft tissues (Fig. 5d). Point analyses reveal that there is more zinc and calcium in the tadpole (1327 and $6451 \mathrm{ppm}$, respectively) than in the matrix (168 and $4182 \mathrm{ppm}$, respectively) (Table 1).

\section{XANES}

The XANES spectrum of the FS003b tadpole has many features in common with those of the blonde human hair and the organic zinc acetate standard, has some similarities to the black human hair and is distinctly dissimilar to both the inorganic standards (zinc foil and sulfate) (Fig. 6a). The tadpole and hairs all show a bifurcated peak, though it is much less pronounced in the black hair, and the pattern of peak dominance varies. The similarities and differences are much clearer in the first derivative plot (Fig. 6b). The gross features of both the inorganic zinc sulfate and the organic samples including zinc acetate are similar as they are all oxygen coordinated; however, the zinc sulfate contains additional distinct higher energy peaks that are not seen in either the tadpole or in any of the other organic samples. There seems to be a shift in the maxima of the black hair; the reasons for this are currently unclear and are the subject of ongoing work. There are no similar peaks in the zinc foil compared to the tadpole. The tadpole spectrum also shows no similarity to other inorganic zinc minerals from the literature, including willemite $\left(\mathrm{Zn}_{2} \mathrm{SiO}_{4}\right)$, zincite $(\mathrm{ZnO})$ and franklinite $\left(\mathrm{ZnFe}_{2} \mathrm{O}_{4}\right)$ (Roberts et al. 2002; Waychunas et al. 2003). Linear combination analysis shows that of the standards analysed, the tadpole XANES spectrum most resembles the zinc acetate 


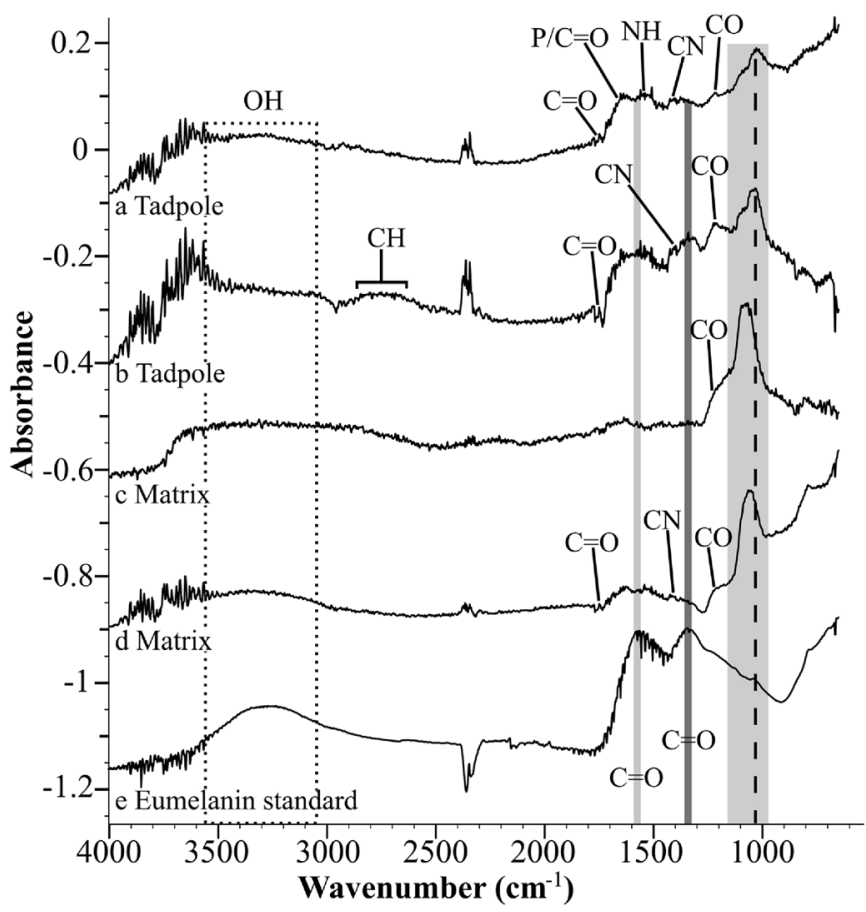

Fig. 4 FTIR spectra from FS003b and a eumelanin standard, with a photograph indicating where spectra were sampled, white open circles. The grey band represents inorganic silicon groups from mineral components; the peak appears slightly shifted in the tadpole compared to the

and blonde hair (Table 2, Fig. 7). In order to see better separation of peaks for determining oxidation state, the first derivative of the normalized absorbance was used (Fig. 6b). The tadpole edge occurs closest to that of the blonde hair and close to the zinc acetate unsurprisingly indicating a +2 oxidation state. The similarity to zinc acetate also indicates that the zinc in both the tadpole and blonde hair is light element bound. However, the fact that the spectra are not identical indicates a subtle difference in coordination chemistry.

\section{EXAFS}

A phase shift is visible at approximately $k=3.7$, between the zinc sulfate, acetate and tadpole (FS003b) (Fig. 8a-c). There is also an additional feature at $k=6.6$, which appears as a prominent shoulder on the second oscillation of the zinc acetate and FS003b tadpole, but at a much lower intensity in the zinc

Table 2 Combinatorial analysis comparing the XANES of the fossil tadpole (FS003b) to standards containing zinc and a modern blonde human hair. The R-factor represents the sum of the squares of the residuals

\begin{tabular}{ll}
\hline Standards & FS003b tadpole \\
\hline Blonde human hair & 0.40 \\
Black human hair & 0.00 \\
Zinc acetate & 0.62 \\
Zinc sulfate & 0.00 \\
Zinc foil & 0.00 \\
R-factor & 0.000845 \\
\hline
\end{tabular}

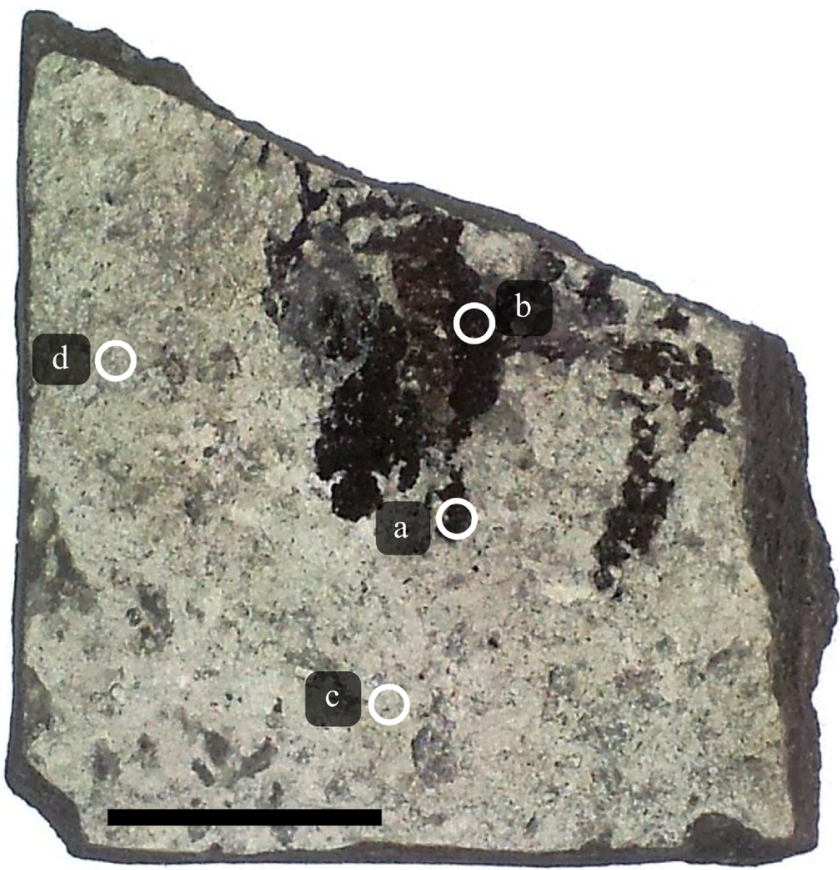

matrix (dashed line). All spectra also appear to have a broad $\mathrm{OH}$ band, shown in the dotted box, and there is evidence of both major melanin $\mathrm{C}=$ $\mathrm{O}$ groups in the tadpole (grey lines)

sulfate. This shows that the zinc coordination in the tadpole is most comparable to that in the zinc acetate.

All three radial distribution functions are similar to each other, reflecting the dominant first-shell oxygen distance (Fig. 8d-f, radial distances given in Table 3). Zinc in all three
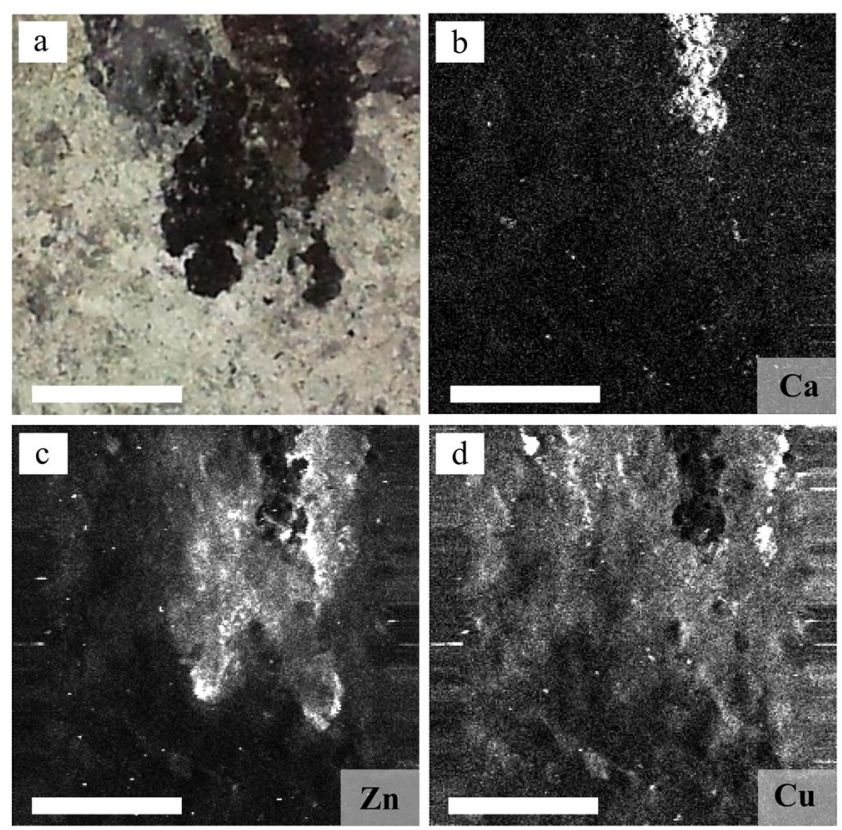

Fig. 5 Comparative photographic (a) and SRS-XRF images of FS003b (b-d). Scale bars represent $1 \mathrm{~cm}$. In (b-d), white indicates high elemental levels and black indicates low levels 


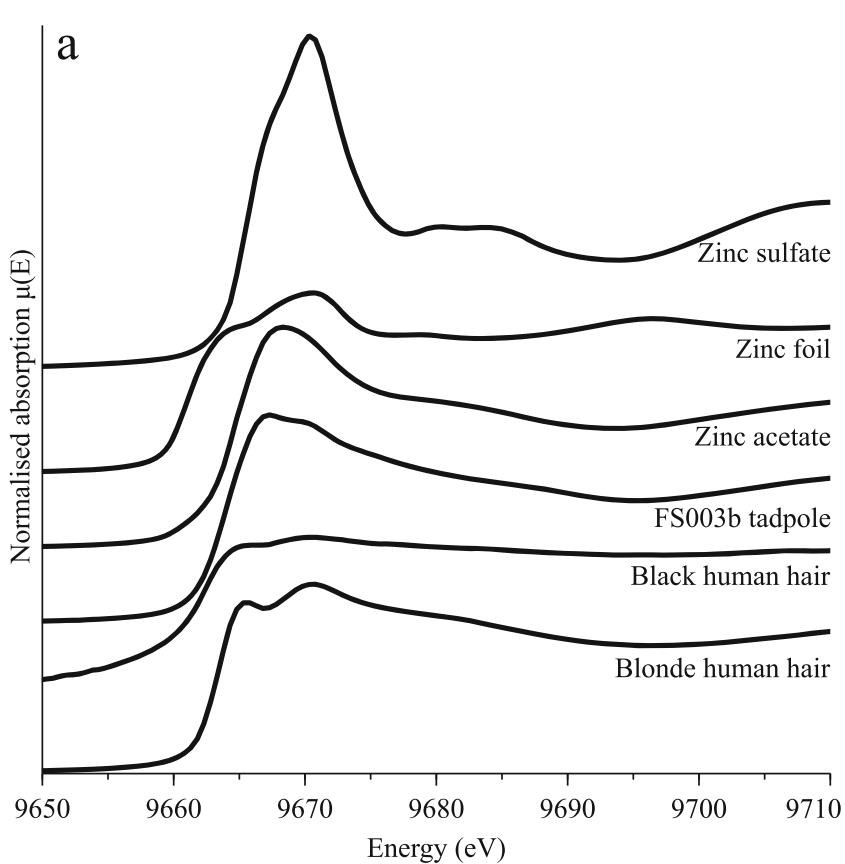

Fig. 6 XANES spectra of zinc standards, blonde human hair and FS003b tadpole at the zinc K edge shown as the normalized absorption (a) and the first derivative (b). All first derivative spectra except the zinc foil are

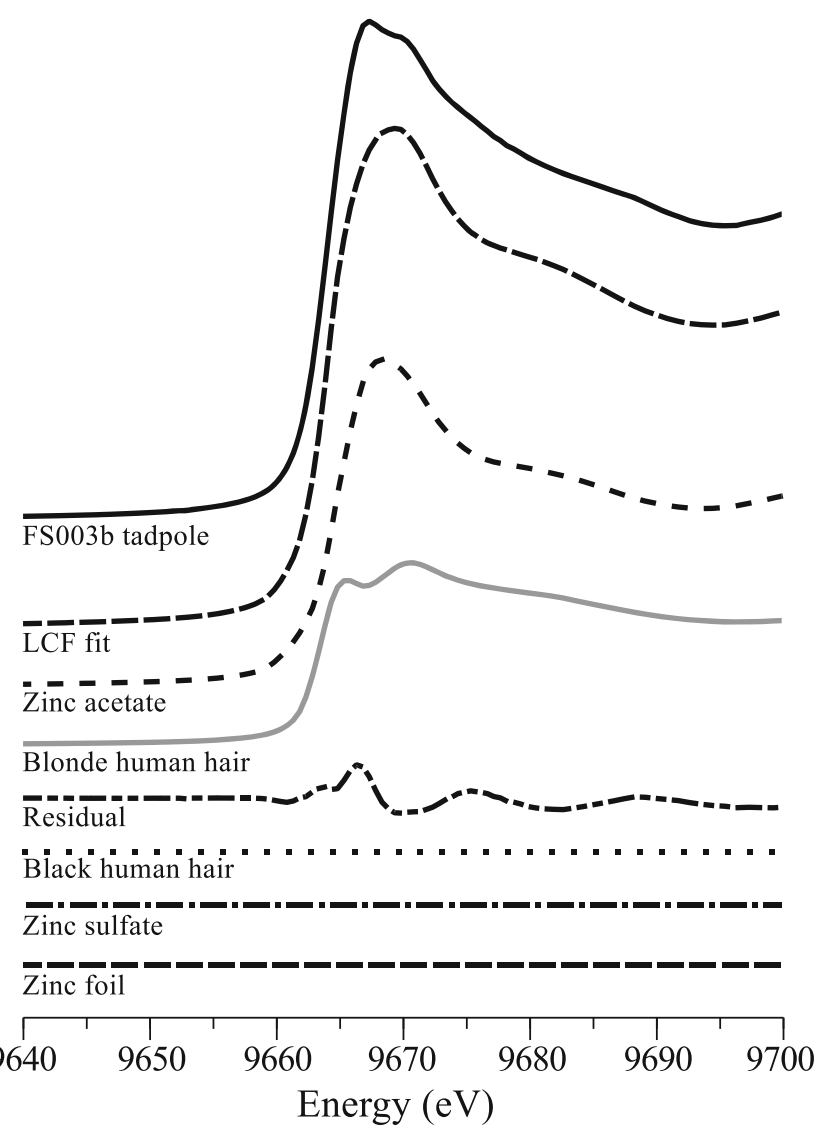

Fig. 7 Linear combination analysis for FS003b

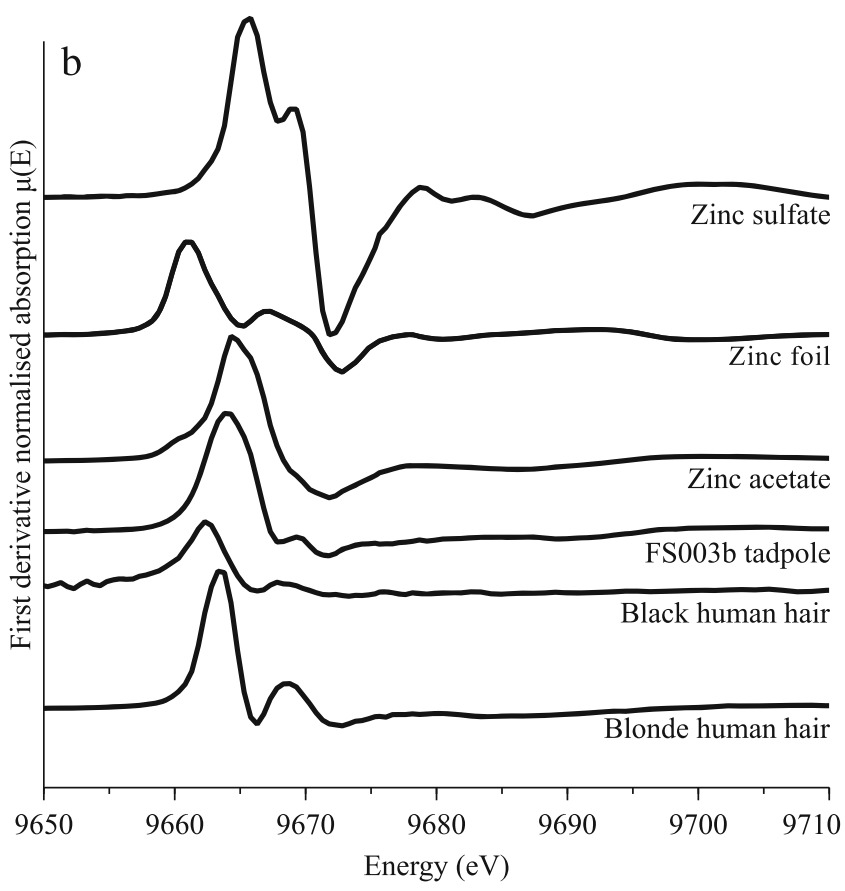

similar as they are all light element coordinated; however, the zinc sulfate also displays additional peaks at higher energies that are not seen in the organic samples

cases is coordinated to four proximate and regularly spaced oxygens as in zinc acetate. By analogy with the configuration in the standard, we also infer that there are two loosely bound vicinal oxygens in the first shell of zinc in the tadpole to complete the expected sixfold geometry. These will be weakly bound and not fixed in position hence only contribute weakly to the absorption spectrum. The tadpole fossil however also shows a distinct shoulder on the distal side of the main peak, and least square fitting indicates that this is most probably caused by the presence of approximately $5 \%$ sulfur in the first shell. This suggests that the zinc in the fossil is in mixed coordination, mostly coordinated to oxygen but with a small percentage bound directly to sulfur.

\section{Discussion}

Physical structure

The cracked nature of the carbonaceous film of the tadpole, presence of small spherical bodies on its surface, and abundance of carbon and sulfur as seen in EDS are all found in other studies of such samples (Toporski et al. 2002; McNamara et al. 2009). As they have observed, the spherical bodies are fully comparable in both size and form to coccoid bacteria; however they are also of a similar form to pheomelanosomes in extant tissues (Fig. 1h). The presence of the pigment pheomelanin, contained within pheomelanosomes, has recently been demonstrated in amphibian skin (Wolnicka-Glubisz et al. 2012); however this does not 

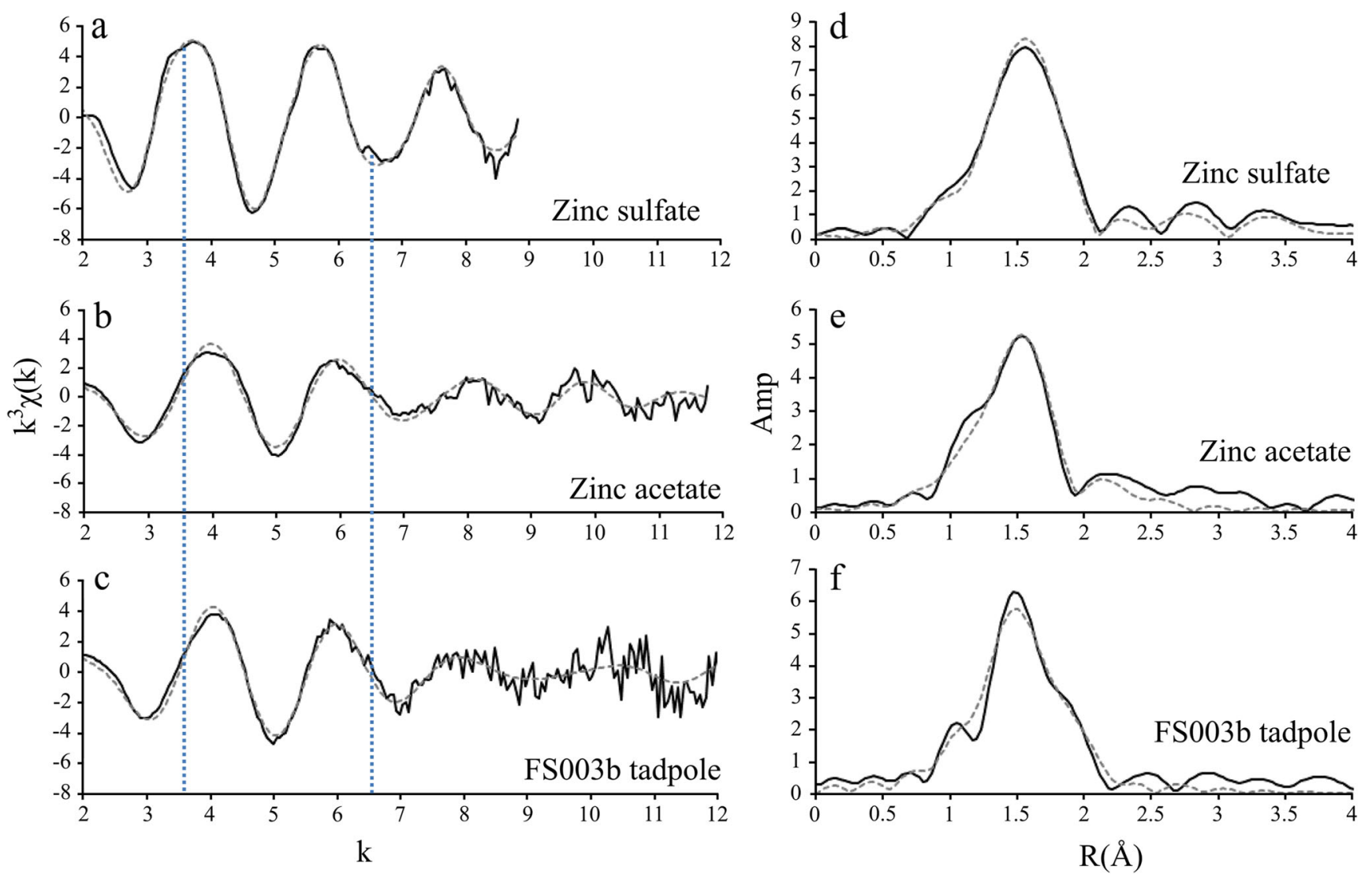

Fig. 8 a-c EXAFS spectra (solid lines) with fits (dashed lines) of zinc sulfate $\left(\mathrm{ZnSO}_{4} \cdot 7 \mathrm{H}_{2} \mathrm{O}\right)$, zinc acetate and the high zinc area of the FS003b tadpole. The dotted vertical line at $k=3.7$ shows the presence of a phase shift between the zinc sulfate and the other two samples. There is also an additional feature at $k=6.6$, appearing as a prominent shoulder on the second oscillation of the zinc acetate and FS003b tadpole, but at a much

appear to be common. The reliance on the geometry of fossilized melanosomes to denote original colour has also been shown to be unreliable due to the effects of diagenesis. Recent work (McNamara et al. 2013) has demonstrated that melanosome shape can change dramatically when exposed to high temperatures and pressures and therefore should not be taken as a definitive indicator of the type of melanin present. Indeed, though eumelanin in extant organisms is generally found in elongate melanosomes, a study identifying eumelanin in a Jurassic cephalopod found its ink sacs were covered in spherical bodies (Glass et al. 2012).

\section{Organic geochemistry}

The presence of sulfur in other fossil tadpoles has been cited as evidence of organosulfur compounds which potentially aid the preservation of the organism by the process of sulfurization (McNamara et al. 2006). Sulfur may also be indicative of the presence of pheomelanin, as the sulfur-containing amino acid cysteine is one of the key triggers for its formation (Robins 1991; Prota 1992); however, we find no evidence of this in our lower intensity in the zinc sulfate. This shows that the zinc coordination in the fossil is most comparable to that of zinc acetate. $\mathbf{d}-\mathbf{f}$ Radial distribution functions (not phase shifted) for zinc within the same three phases are shown. The solid lines represent the data; the dashed lines represent the fits

samples. There is also no evidence of eu- or pheomelanin breakdown products in the Py-GCMS chromatograms (Dworzanski and Debowski 1985; Latocha et al. 2000), which show the presence of generic organic matter, including series of benzene and naphthalene compounds.

Though the distribution pattern of $n$-alkane/ $n$-alkene doublets is slightly different in the tadpole and its enclosing matrix, it is not different enough to rule out the possibility of some organic matter transfer. However, the fact that the distribution patterns of fatty acid methyl esters are distinctly different makes this scenario very improbable, indicating that the organic material of the tadpole is most likely endogenous to the original organism. This is strengthened by the detection of phytol, indicative of plant material, in the matrix and not the tadpole, though it is only present in trace amounts. This runs counter to previous studies where this incorporation of molecular plant material has been suggested as the mechanism for the darkening of the carbonaceous film in such samples (Franzen 1985). The fact that a series of bacterial hopane compounds was detected in the matrix but not in the tadpole (Fig. 2) is suggestive but not conclusive of the absence of 
Table 3 Zinc K $\alpha$ EXAFS analysis of standards and the Enspel tadpole (radial distances $[\mathrm{r}]$ in ångstroms). Values in parentheses are theoretical values for the standards

\begin{tabular}{lllll}
\hline & & Zn-sulfate & Zn-acetate & FS003b tadpole \\
\hline O1 & $r$ & $2.085(2.06-2.12)$ & $1.989(1.987)$ & 1.981 \\
& $N$ & $5.72(6)$ & $4.03(2)$ & 2.97 \\
& $\sigma^{2}$ & 0.009 & 0.010 & 0.008 \\
O2 & $r$ & $4.151(4.178)$ & $2.051(2.184)$ & 2.14 \\
& $N$ & $4.33(4)$ & $0.33(4)$ & 0.43 \\
& $\sigma^{2}$ & 0.146 & 0.002 & 0.001 \\
O3 & $r$ & $3.267(3.5-3.7)$ & & \\
& $N$ & $0.72(24)$ & & \\
& $\sigma^{2}$ & 0.001 & & 2.677 \\
C3 & $r$ & & $2.688(2.552)$ & 1.31 \\
& $N$ & & $0.92(2.55)$ & 0.011 \\
& $\sigma^{2}$ & & $0.001^{\mathrm{a}}$ & 2.313 \\
S4 & $r$ & & & 0.19 \\
& $N$ & & & 0.001 \\
& $\sigma^{2}$ & & & 0.94 \\
So2 & & 0.99 & 0.70 & 2.58 \\
$\mathrm{E}_{o}$ & & 0.90 & 0.60 & 0.0508 \\
$\mathrm{R}$ & & 0.0196 & 0.0561 & \\
\hline
\end{tabular}

${ }^{a}$ Parameter fixed during fitting

bacteria in the tadpole; it shows only the absence of aerobic bacteria. Indeed, there is potential evidence of bacterial chain structures on both matrix and tadpole (Fig. 1f, g) though this identification is not certain. The FTIR data suggests the presence of amino acids $(\mathrm{C}=\mathrm{O}, \mathrm{NH}$ and $\mathrm{CN}$ groups) within the tadpole and matrix. Given that the organic material of the tadpole is most likely to be endogenous, this suggests the amino acids are from the original tadpole tissues, whereas in the matrix, the signal is most likely from bacteria. However, the functional groups do not allow the identification of specific amino acids, and therefore, this distinction is again inconclusive. One area of the tadpole does however seem to show both $\mathrm{C}=\mathrm{O}$ ketone and carboxylic acid peaks seen in eumelanin (Fig. 4); the $\mathrm{C}=\mathrm{O}$ carboxylic acid group at $1350 \mathrm{~cm}^{-1}$ in particular is only seen in the tadpole. This is suggestive but not conclusive of the presence of melanin, due to the likely presence of co-occurring inorganic mineral peaks. Additionally, despite the fact that FTIR is useful in identifying melanin, it has been shown to be less so in distinguishing between eumelanin and pheomelanin (Liu et al. 2005).

\section{Trace metals}

Whilst levels of copper are higher in the fossil than the matrix, levels of zinc are much higher. This suggests that there is no or very little eumelanin present (Wogelius et al. 2011). The presence of zinc in fossilized tadpoles has been noted before
(McNamara et al. 2009), but this is the first time it has been shown to be organometallic $\mathrm{Zn}$ (II) and to occur throughout the soft tissues. $\mathrm{Zn}(\mathrm{II}), \mathrm{Cu}$ (II), $\mathrm{Mg}(\mathrm{II}), \mathrm{Fe}(\mathrm{III})$ and $\mathrm{Ca}(\mathrm{II})$ are the most common metals present within both eu- and pheomelanin (Liu et al. 2005). In solutions of mild acidic or neutral $\mathrm{pH}, \mathrm{Cu}$ (II) and $\mathrm{Zn}$ (II) have a higher binding affinity to eumelanin than $\mathrm{Mg}$ (II) and $\mathrm{Ca}$ (II) (Liu et al. 2004). Melanin can act like a metal ion sink during diagenesis, leading to the build-up of these metals where melanin was present and allowing them to be used as a melanin biomarker (Wogelius et al. 2011). Zinc is known to naturally accumulate in red human hair, and levels of zinc commonly exceed those of copper in eu-and pheomelanin extracted from human hair (Latocha et al. 2000). Another reason for higher zinc levels in the tadpole may be the presence of matrix metalloproteinases. These enzymes are interstitial collagenases (Brinckerhoff and Matrisian 2002) and members of the metzincin group of proteins, so named for, among other things, their dependence on the $\mathrm{Zn}$ (II) ion (Page-McCaw et al. 2007). These enzymes were first described after their study in tadpoles (Gross and Lapiere 1962) and are an essential part of the process of metamorphosis they undergo to develop an adult body. The tadpoles' dependence on this protein may have increased the amount of zinc present within the tissues before death which could have subsequently become chelated to any melanin present and thereby retained in the soft tissues.

Whilst XANES and EXAFS data attest to the organic nature of the zinc and its similarity to that in pheomelanic samples, a comparison to such analyses of a pure pheomelanin sample as well as to bacterially bound zinc would be necessary to confirm or refute the presence of pheomelanin in the tadpole. The zinc in the human hair is also not a pure sample; there are likely to be contributions from both eu- and pheomelanin-bound zinc as well as that in proteins. The zinc XANES spectrum of the tadpole is also somewhat similar to that of zinc bound to bacterial enzymes (Meyer-Klaucke et al. 1999; Outten et al. 2001).

\section{Conclusions}

- The fossil tadpole is covered in small spherical bodies consistent in size and form with both coccoid bacteria and pheomelanosomes.

- The tadpole is preserved as a thin, carbon-rich, organic film, with no evidence of secondarily precipitated minerals on its surface.

- The organic material in the tadpole is different from that in the encasing matrix and is therefore most likely original to the organism and not a result of transfer from the matrix. This rules out the possibility that the carbonaceous layer of 
the tadpole being a result of the incorporation of plant material.

- Py-GCMS indicates the presence of bacterial biomarkers in the matrix but not the tadpole, though this does not completely rule out the possibility of there being bacteria on the tadpole

- FTIR shows possible melanin groups in the tadpole but not the matrix; SRS-XRF analyses show high levels of zinc are associated with the soft tissues of the tadpole, and XANES and EXAFS indicate the zinc to be organic $\mathrm{Zn}$ (II) comparable to that seen in blonde human hair. Though further analysis of zinc in both pure pheomelanin and bacterial samples is required to completely exclude a bacterial origin, these results are in line with a pheomelanic origin.

Acknowledgements Samples were kindly provided by M. Wuttke of the General Department of Cultural Heritage Rhineland Palatinate, Germany. FTIR analysis facilities were provided by K. Palmer of PerkinElmer and ESEM facilities by V. Vishnyakov of the DRIAM Analytical Service funded by the ESPRC. HEB was supported by NERC studentship grant. The authors would like to acknowledge the valuable contributions of two anonymous reviewers

Open Access This article is distributed under the terms of the Creative Commons Attribution License which permits any use, distribution, and reproduction in any medium, provided the original author(s) and the source are credited.

\section{References}

Anné J, Edwards NP, Wogelius RA, Tumarkin-Deratzian AR, Sellers WI, van Veelen A, Bergmann U, Sokaras D, Alonso-Mori R, Ignatyev K, Egerton VM, Manning PL (2014) Synchrotron imaging reveals bone healing and remodelling strategies in extinct and extant vertebrates. J R Soc Interface 11(96). doi:10.1098/rsif.2014.0277

Barden HE, Wogelius RA, Li D, Manning PL, Edwards NP, van Dongen BE (2011) Morphological and geochemical evidence of eumelanin preservation in the feathers of the Early Cretaceous bird, Gansus yumenensis. PLoS One 6(10):e25,494. doi:10.1371/journal.pone. 0025494

Bergmann U, Manning PL, Wogelius RA (2012) Chemical mapping of paleontological and archeological artifacts with synchrotron $\mathrm{x}$-rays. Annu Rev Anal Chem 5(1):361-389. doi:10.1146/annurev-anchem062011-143019, pMID:22524223

Briggs DEG, Wilby PR (1996) The role of the calcium carbonate-calcium phosphate switch in the mineralization of soft-bodied fossils. J Geol Soc London 153(5):665-668. doi:10.1144/gsjgs.153.5.0665

Briggs DEG, Wilby PR, Perez-Moreno BP, Sanz JL, Fregenal-Martinez M (1997) The mineralization of dinosaur soft tissue in the Lower Cretaceous of Las Hoyas, Spain. J Geol Soc London 154:587-588. doi:10.1144/gsjgs.154.4.0587

Briggs DEG, Moore RA, Shultz JW, Schweigert G (2005) Mineralization of soft-part anatomy and invading microbes in the horseshoe crab Mesolimulus from the Upper Jurassic Lagerstatte of Nusplingen, Germany. P R Soc B 272(1563):62732. doi:10.1098/rspb.2004. 3006
Brinckerhoff CE, Matrisian LM (2002) Matrix metalloproteinases: a tail of a frog that became a prince. Nat Rev Mol Cell Bio 3(March):207214. doi: $10.1038 / \mathrm{nrm} 763$

Carney RM, Vinther J, Shawkey MD, D'Alba L, Ackermann J (2012) New evidence on the colour and nature of the isolated Archaeopteryx feather. Nat Commun 3:637. doi:10.1038/ncomms1642

Clarke JA, Ksepka DT, Salas-Gismondi R, Altamirano AJ, Shawkey MD, D'Alba L, Vinther J, DeVries TJ, Baby P (2010) Fossil evidence for evolution of the shape and color of penguin feathers. Science 330(6006):954-957. doi:10.1126/science.1193604

Cristol D, Armstrong J, Whitaker J, Forsyth M (2005) Feather-degrading bacteria do not affect feathers on captive birds. Auk 122(1):222230. doi:10.1642/0004-8038(2005)122[0222:FBDNAF]2.0.CO;2

Downs RT (2006) The RRUFF Project: an integrated study of the chemistry, crystallography, Raman and infrared spectroscopy of minerals. In: 19th General Meeting of the International Mineralogical Association, Kobe, pp O03-O13

Dworzanski JP, Debowski M (1985) Pyrolysis-gas chromatography of pheomelanins. J Anal Appl Pyrol 8:463-472. doi:10.1016/01652370(85)80044-9

Edwards NP, Manning PL, Bergmann U, Larson PL, van Dongen BE, Sellers WI, Webb SM, Sokaras D, Alonso-Mori R, Ignatyev K, Barden HE, van Veelen A, Anné J, Egerton VM, Wogelius RA (2014) Leaf metallome preserved over 50 million years. Metallomics 6:774-782. doi:10.1039/ C3MT00242J

Franzen JL (1985) Exceptional preservation of Eocene vertebrates in the lake deposit exceptional preservation of Grube Messel (West Germany). Philos T Roy Soc B 311(1148):181-186. doi:10.1098/ rstb. 1985.0150

Gehling JG (1999) Microbial mats in terminal Proterozoic siliciclastics; Ediacaran death masks. Palaios 14(1):40-57. doi: $10.2307 / 3515360$

Glass K, Ito S, Wilby PR, Sota T, Nakamura A, Bowers CR, Vinther J, Dutta S, Summons R, Briggs DEG, Wakamatsu K, Simon JD (2012) Direct chemical evidence for eumelanin pigment from the Jurassic period. Proc Natl Acad Sci U S A 109(26):10,218-23. doi:10.1073/ pnas. 1118448109

Gosner KL (1960) A simplified table for staging anuran embryos and larvae with notes on identification. Herpetologica 16:183-190

Gross J, Lapiere CM (1962) Collagenolytic activity in amphibian tissue: a tissue culture assay. Proc Natl Acad Sci U S A 48:1014-1022

Gupta NS, Briggs DEG, Collinson ME, Evershed RP, Michels R, Jack KS, Pancost RD (2007a) Evidence for the in situ polymerisation of labile aliphatic organic compounds during the preservation of fossil leaves: implications for organic matter preservation. Org Geochem 38(3):499-522. doi:10.1016/j. orggeochem.2006.06.011

Gupta NS, Briggs DEG, Collinson ME, Evershed RP, Michels R, Pancost $\mathrm{RD}$ (2007b) Molecular preservation of plant and insect cuticles from the Oligocene Enspel Formation, Germany: evidence against derivation of aliphatic polymer from sediment. Org Geochem 38(3): 404-418. doi:10.1016/j.orggeochem.2006.06.012

Gupta NS, Michels R, Briggs DG, Collinson ME, Evershed RP, Pancost RD (2007c) Experimental evidence for the formation of geomacromolecules from plant leaf lipids. Org Geochem 38(1):28-36. doi:10.1016/j. orggeochem.2006.09.014

Latocha M, Chodurek E, Kurkiewicz S, Swiatkowska L, Wilczok T (2000) Pyrolytic GC-MS analysis of melanin from black, gray and yellow strains of Drosophila melanogaster. J Anal Appl Pyrol 56(1): 89-98. doi:10.1016/S0165-2370(00)00082-6

Li Q, Gao KQ, Vinther J, Shawkey MD, Clarke JA, D'Alba L, Meng Q, Briggs DEG, Prum RO (2010) Plumage color patterns of an extinct dinosaur. Science 327(5971):1369-1372. doi:10.1126/science. 1186290

Li Q, Gao KQ, Meng Q, Clarke JA, Shawkey MD, D'Alba L, Pei R, Ellison M, Norell MA, Vinther J (2012) Reconstruction of 
microraptor and the evolution of iridescent plumage. Science 335(March):1215-1219. doi:10.1126/science.1213780

Lindgren J, Uvdal P, Sjövall P, Nilsson DE, Engdahl A, Schultz BP, Thiel V (2012) Molecular preservation of the pigment melanin in fossil melanosomes. Nat Commun 3(may):824. doi: 10.10310.1126/science.12137808/ncomms1819

Lindgren J, Sjövall P, Carney RM, Udval P, Gren JA, Dyke G, Schultz BP, Shawkey MD, Barnes KR, Polcyn MJ (2014) Skin pigmentation provides evidence of convergent melanism in extinct marine reptiles. Nature 506:484-488. doi:10.1038/nature12899

Liu Y, Hong L, Kempf VR, Wakamatsu K, Ito S, Simon JD (2004) Ionexchange and adsorption of Fe(III) by Sepia melanin. Pigm Cell Res 17(3):262-269. doi:10.1111/j.1600-0749.2004.00140.x

Liu Y, Hong L, Wakamatsu K, Adhyaru B, Cheng C, Bowers CR, Simon JD (2005) Comparisons of the structural and chemical properties of melanosomes isolated from retinal pigment epithelium, iris and choroid of newborn and mature bovine eyes. Photochem Photobiol 81:510-516. doi:10.1562/200410-19-RA-345.1

Manning PL, Morris PM, McMahon A, Jones E, Gize A, Macquaker JHS, Wolff G, Thompson A, Marshall J, Taylor KG, Lyson T, Gaskell S, Reamtong O, Sellers WI, van Dongen BE, Buckley M, Wogelius RA (2009) Mineralized soft-tissue structure and chemistry in a mummified hadrosaur from the Hell Creek Formation, North Dakota (USA). P R Soc B 276(1672):3429-3437. doi:10.1098/rspb. 2009.0812

McNamara ME, Orr PJ, Kearns SL, Alcalá L, Anadón P, Peñalver Mollá E (2006) High-fidelity organic preservation of bone marrow in ca. 10 Ma amphibians. Geology 34(8):641

McNamara ME, Orr PJ, Kearns SL, Alcalá L, Anadón P, Peñalver Mollá E (2009) Soft-tissue preservation in Miocene frogs from Libros, Spain: insights into the genesis of decay microenvironments. Palaios 24(2):104-117. doi:10.2110/palo.2008.p08-017r

McNamara ME, Orr PJ, Kearns SL, Alcalá L, Anadón P, Peñalver Mollá E (2010) Exceptionally preserved tadpoles from the Miocene of Libros, Spain: ecomorphological reconstruction and the impact of ontogeny upon taphonomy. Lethaia 43(3):290-306. doi:10.1111/j. 1502-3931.2009.00192.x

McNamara ME, Briggs DEG, Orr PJ, Field D, Wang Z (2013) Experimental maturation of feathers: implications for reconstructions of fossil feather colour. Biol Letters 9(3):20130,184. doi:10. 1098/rsbl.2013.0184

Meyer-Klaucke W, Paul Soto R, Hernandez Valladares M, Adolph HW, Nolting HF, Frère JM, Zeppezauer M (1999) A comparison of Bacillus cereus and Aeromonas hydrophilia Zn-beta-lactamases. J Synchrotron Radiat 6(Pt 3):400-402. doi:10.1107/ S0909049598017816

Moyer AE, Zheng W, Johnson EA, Lamanna MC, Li D, Lacovara KJ, Schweitzer MH (2014) Melanosomes or microbes: testing an alternative hypothesis for the origin of microbodies in fossil feathers. Sci Rep 4:4233. doi:10.1038/srep04233

Outten CE, Da T, Penner-Hahn JE, O'Halloran TV (2001) Characterization of the metal receptor sites in Escherichia coli Zur, an ultrasensitive zinc(II) metalloregulatory protein. Biochem-US 40(35):10,417-23. doi:10.1021/bi0155448

Page-McCaw A, Ewald AJ, Werb Z (2007) Matrix metalloproteinases and the regulation of tissue remodelling. Nat Rev Mol Cell Bio 8(3): 221-233. doi:10.1038/nrm2125

Prota G (1992) Melanins and melanogenesis. Academic press, Michigan
Ravel B, Newville M (2005) ATHENA, ARTEMIS, HEPHAESTUS: data analysis for X-ray absorption spectroscopy using IFEFFIT. J Synchrotron Radiat 12(Pt 4):537-541. doi:10.1107/ S0909049505012719

Roberts DR, Scheinost C, Sparks DL (2002) Zinc speciation in a smeltercontaminated soil profile using bulk and microspectroscopic techniques. Environ Sci Technol 36(8):1742-1750. doi:10.1021/ es015516c

Robins AH (1991) Biological perspectives on human pigmentation. Cambridge University Press, New York

Roček Z (2003) Larval development in Oligocene palaeobatrachid frogs. Acta Palaeontol Pol 48(4):595-607

Schneider CA, Rasband WS, Eliceiri KW (2012) NIH image to ImageJ: 25 years of image analysis. Nat Methods 9(7):671-675. doi:10. 1038/nmeth.2089

Solé V, Papillon E, Cotte M, Walter P, Susini J (2007) A multiplatform code for the analysis of energy-dispersive $\mathrm{X}$-ray fluorescence spectra. Spectrochim Acta B 62(1):63-68. doi:10.1016/j.sab.2006.12. 002

Stankiewicz BA, Briggs DEG, Michels R, Collinson ME, Flannery MB, Evershed RP (2000) Alternative origin of aliphatic polymer in kerogen. Geology 28(6):559-562. doi:10.1130/0091-7613(2000) 28<559:AOOAPI $>2.0$. CO;2

Toporski J, Steele A, Westall F, Avci R, Martill DM, McKay DS (2002) Morphologic and spectral investigation of exceptionally wellpreserved bacterial biofilms from the Oligocene Enspel formation, Germany. Geochim Cosmochim Ac 66(10):1773-1791. doi:10. 1016/S0016-7037(01)00870-5

Vinther J, Briggs DEG, Prum RO, Saranathan V (2008) The colour of fossil feathers. Biol Letters 4(5):522-525. doi:10.1098/rsbl.2008.0302

Waychunas G, Fuller C, Davis J, Rehr J (2003) Surface complexation and precipitate geometry for aqueous $\mathrm{Zn}$ (II) sorption on ferrihydrite: II. XANES analysis and simulation. Geochim Cosmochim Ac 67(5): 1031-1043. doi:10.1016/S0016-7037(02)01280-2

Webb SM (2005) SIXpack: a graphical user interface for XAS analysis using IFEFFIT. Phys Scripta 2005(T115):1011. doi:10.1238/ Physica.Topical.115a01011

Wilby PR, Briggs DEG, Bernier P, Gaillard C (1996) Role of microbial mats in the fossilization of soft tissues. Geology 24(9):787-790. doi: 10.1130/0091-7613(1996)024 0787:rommit 2.3.co;2

Wogelius RA, Manning PL, Barden HE, Edwards NP, Webb SM, Sellers WI, Taylor KG, Larson PL, Dodson P, You H, Da-qing L, Bergmann U (2011) Trace metals as biomarkers for eumelanin pigment in the fossil record. Science 333(6049):1622-1626. doi:10.1126/science.1205748

Wolnicka-Glubisz A, Pecio A, Podkowa D, Kolodziejczyk LM, Plonka PM (2012) Pheomelanin in the skin of Hymenochirus boettgeri (Amphibia: Anura: Pipidae). Exp Dermatol 21(7):537-540. doi:10. 1111/j.1600-0625.2012.01511.x

Wuttke M (1983) Weichteilerhaltung durch lithifizierte Mikroorganismen bei mittel-eozänen Vertebraten aus dem Ölschiefer der "Grube Messel" bei Darmstadt. Senck leth 64:503-527

Wuttke M (1992) Messel: an insight into the history of life and of the earth. In: Schaal S, Ziegler W (eds) Conservation-dissolution-transformation. On the behaviour of biogenic materials during fossilization, vol 24, Wuttke M. Clarendon, Oxford, pp 263-275

Zhang F, Kearns SL, Orr PJ, Benton MJ, Zhou Z, Johnson D, Xu X, Wang X (2010) Fossilized melanosomes and the colour of cretaceous dinosaurs and birds. Nature 463(7284):1075-1078. doi:10. 1038/nature 08740 